\title{
Interactive comment on "Temporal variability of social vulnerability to storm surges in Shenzhen, China” by Huaming Yu et al.
}

Huaming Yu et al.

hmyu@ouc.edu.cn

Received and published: 12 February 2020

The research group thanks Anonymous Reviewer \#1 for their detailed comments and supportive suggestions. This feedback allows our group to make appropriate updates to the manuscript in preparation for uploading an improved version.

Please see the supplement PDF for our responses to all general comments and specific comments.

Please also note the supplement to this comment:

Printer-friendly version https://www.nat-hazards-earth-syst-sci-discuss.net/nhess-2019-293/nhess-2019-293-

Discussion paper AC1-supplement.pdf 
Interactive comment on Nat. Hazards Earth Syst. Sci. Discuss., https://doi.org/10.5194/nhess2019-293, 2019.

\section{NHESSD}

Interactive

comment 